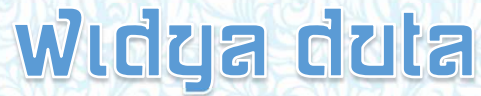

JURNAL ILMIAH ILMU AGAMA DAN ILMU SOSIAL BUDAYA

\section{Upaya Pembentukan Brand Awareness di Dalam Negeri oleh Triple S}

Shamit Roidisom, Hanny Hafiara, Evi Novianti

Program Studi Ilmu Hubungan Masyarakat, Fakultas Ilmu

Komunikasi,Universitas Padjadjaran

Abstract

Keywords
PT Triple S is known as sport kit factory in Indonesia, and specialist of soccer ball. PT Triple $S$ has a good product, however the brand itself acknowledged internationally better than domestically. Brand awareness is built through marketing communication. Therefore, this case study inquiry is trying to identify the technique of creating brand awareness with marketing communication strategy by PT Sinjaraga Santika Sport (Triple S) in Indonesia. The goal of this research is to have knowledge of creating brand awareness technique using marketing communication by PT Sinjaraga Santika Sport (Triple S). This study is utilizing qualitative approach, constructivism paradigm and case study as form of study. The Subject were people who is implicated by brand awareness strategy of PT Triple S, for instance employees and customer of PT Triple S.The results of this research gave out that marketing communication is being done by PT Triple $S$ in order to create brand awareness in Indonesia. But, the inhibition both internal obstacle (from the company itself) for example uncertainty of human resources's skill on executing marketing communication strategy and external obstacle (Indonesian consumer stereotype that think import products are better than local product) has created the fact that brand of Triple $S$ is acknowledged better internationally than domestically. As for the closure of this research: marketing communication strategies that successfully creates brand awareness internationally are their ball officially certified by FIFA, they also had an agreement and entered World Cup 1998. Meaanwhile marketing communication is also being donein Indonesia but the obstacles both internal and external has caused a misfortune for PT Triple $S$ in order to create brand awareness domestically.

Marketing communication brand awareness, Triple S' Ball, PT Triple S

a hannyhafiar@gmail.com 


\section{PENDAHULUAN}

PT Triple $\mathrm{S}$ adalah sebuah perusahaan yang memproduksi bola sepak di Indonesia, sebagai salah satu perusahaan besar yang berada di Indonesia sejak tahun 1994, PT Triple S memiliki banyak catatan prestasi. Salah satunya bola produk Triple $S$ pernah digunakan oleh para pemain dunia pada ajang perhelatan sepakbola terbesar yaitu Piala Dunia yang kala itu diselenggarakan di Perancis pada tahun 1998. Pada saat itu PT Triple S bekerjasama dengan perusahaan besar milik Jerman yaitu Adidas untuk memproduksi bola untuk digunakan pada Piala Dunia. Sejak saat itu brand Triple $S$ menjadi terkenal di beberapa negara di Dunia.

Ada kenyataan yang menarik dengan prestasinya tersebut, dan banyak prestasi lainnya, yaitu popularitas brand atau merek Triple $S$ di luar negeri tidak diikuti dengan popularitas mereknya di dalam negeri sendiri. Hal ini didukung dengan pernyataan Direktur EksporImpor PT Triple $S$ yang menyatakan "betul memang selama ini kecenderungan brand kami dikenal lebih baik di luar negeri ketimbang di dalam negeri sendiri." ${ }^{2}$ Jefry juga menambahkan bahwa PT Triple S memiliki negara-negara "langganan" yang biasa memesan bola hingga saat ini seperti, Afrika Selatan, dan Monako. Sementara negara lainnya suka memesan juga namun tidak rutin atau "dadakan". Dengan pernyataan tersebut maka cukup jelas fakta yang ada, dan dapat dikatakan bahwa brand atau merek PT Triple S sebagai produsen bola sepak lebih dikenal di luar negeri daripada di dalam negeri sendiri, padahal brand lokal yang sudah 'go international' dan diakui oleh dunia ini bisa menjadi merek kebanggaan Indonesia. Hal yang senada juga disampaikan oleh Ketua Umum Asosiasi Industri Olahraga Nasional Indonesia (Asioni) sekaligus Komisaris Utama dan pendiri PT Triple S, Irwan Suryanto. Menurutnya kapasitas pabrik bolanya mencapai 100.000 buah/bulan, sebanyak $95 \%$ dikirim untuk kebutuhan ekspor, hanya 5\% dari total digunakan di dalam negeri. "Kalau sekarang sudah 50\%-50\%," katanya. ${ }^{3}$ Irwan juga mengatakan bahwa bolanya dipakai oleh tim negara Kuwait.

Masyarakat Indonesia juga memiliki perilaku konsumtif namun mayoritas masyarakat cenderung menyukai produk luar negeri atau barang impor dibandingkan dengan produk lokal atau buatan dalam negeri hal ini didukung dengan pernyataan dari Pakar Marketing Yuswohady, beliau mengatakan "Kita negara yang terlalu lama di jajah, merek asing dianggap lebih bagus." Dia menambahkan, rakyat Indonesia dinilai tidak menunjukkan sikap percaya terhadap merek lokal. ${ }^{4}$. Hal senada juga diungkapkan oleh seorang Pengamat Ekonomi Muda Banten, Muhammad Nawawi, menurutnya "masyarakat indonesia

\footnotetext{
2 Wawancara dengan Direktur Ekspor-Impor PT Triple S, Jefry Romdoni pada, 11 Mei 2015

${ }^{3}$ http://finance.detik.com/read/2014/02/17/165635/2499948/1036/bola-dan-jersey-ri-tembus-eropaorang-indonesia-lebih-bangga-barang-impor Diakses pada 26 Mei 2015, Pukul 17.44

${ }^{4}$ http://www.merdeka.com/uang/produk-indonesia-diakui-dunia-masyarakat-malah-suka-barangimpor.html Diakses pada 5 September 2015 Pukul 09.46 wib
} 
termasuk dalam kategori penggemar berat barang import" ${ }^{5}$

Sebagai salah satu perusahaan besar yang ada di Indonesia, PT Triple S melakukan komunikasi pemasaran. Komunikasi pemasaran dirancang agar pesan yang disampaikan seseorang atau perusahaan dapat mempengaruhi stimulus dalam kepentingan bisnis yang dilakukan. Komunikasi pemasaran oleh Public Relations dapat juga dilakukan untuk membentuk atau meningkatkan brand awareness publik sasaran terhadap merek. Brand atau merek adalah hal yang penting bagi sebuah perusahaan di dalam dunia bisnis, karena merek adalah identitas perusahaan dan membedakan suatu produk dari perusahaan dengan produk dari perusahaan lainnya, maka membangun kesadaran merek atau brand awareness menjadi suatu hal yang penting bagi perusahaan. Perusahaan besar biasanya memiliki brand awareness yang baik, terlebih ketika perusahaan besar tersebut memiliki prestasi yang baik pula, hal ini dibuktikan dengan perusahaan-perusahaan besar seperti Apple, Adidas, dan Aqua. Meski begitu tidak semua perusahaan besar dengan prestasi yang baik, memiliki brand awareness yang baik pula. Seperti PT Sinjaraga Santika Sport (Triple S) ini dengan mereknya yang lebih dikenal diluar negeri, namun tidak begitu dikenal di dalam negeri sendiri.

Brand dengan fungsinya sebagai identitas perusahaan maka perlu di tanamkan pada diri manajemen perusahaan dengan baik, sehingga pemahaman mengenai brand tersebut tertanam dalam diri manajemen. Apabila dalam benak manajemen telah tertanam, sebagai contoh manajemen memahami brand perusahaannya sebagai brand yang bagus dan berkualitas, maka berdasarkan pemahamannya tersebut dapat dilakukan kegiatan komunikasi pemasaran yang sesuai. Seperti kegiatan yang berbentuk pameran yang mengedepankan kualitas produk dari perusahaan atau kegiatan lainnya.

Adapun keunikan dari kasus ini, ketika perusahaan lain gencar melakukan promosi untuk meningkatkan brand awareness, PT Triple S sukses melakukan komunikasi pemasaran dengan meningkatkan kualitas produk bola sepaknya melalui sertfikasi FIFA yang sulit diperoleh perusahaan lain, hal ini menjadikan peneliti tertarik untuk melakukan penelitian studi kasus mengenai pembentukan brand awareness melalui komunikasi pemasaran, dengan fokus penelitian: "bagaimana komunikasi pemasaran PT Sinjaraga Santika Sport (Triple S) dalam membentuk brand awareness di dalam negeri?" berdasarkan rumusan masalah diatas, peneliti menentukan pertanyaan penelitian yaitu: bagaimana komunikasi pemasaran yang dilakukan oleh PT Triple $S$ sehingga brand nya lebih dikenal di luar negeri dari pada di dalam negeri?; Faktor / hambatan apa saja yang ditemui dalam melakukan komunikasi pemasaran di dalam negeri sehingga brand Triple $\mathrm{S}$ lebih dikenal di luar negeri dari pada di dalam negeri?; Bagaimana upaya komunikasi pemasaran yang dilakukan

\footnotetext{
${ }^{5}$ http://pojokbursa.widyatama.ac.id/perilakukonsumtif-kelas-menengah/ Diakses pada 9 September 2015 Pukul 11.38 wib
} 
PT Triple $S$ dalam meningkatkan brand awareness di dalam negeri?

\section{METODE PENELITIAN}

Penelitian ini menggunakan metode kualitatif dengan pendekatan studi kasus. Penelitian kualitatif (Qualitative research) bertolak dari filsafat konstruktivisme yang berasumsi bahwa kenyataan itu berdimensi jamak, interaktif dan suatu pertukaran pengalaman sosial (a shared social experience) yang diinterpretasikan oleh individu-individu. (Syaodih, 2001 : 94). Penelitian ini menggunakan pendekatan studi kasus. Studi kasus disebut juga riwayat kasus menurut Susilo Rahardjo \& Gudnanto adalah: Suatu metode untuk memahami individu yang dilakukan secara integratif dan komprehensif agar diperoleh pemahaman yang mendalam tentang individu tersebut beserta masalah yang dihadapinya dengan tujuan masalahnya dapat terselesaikan dan memperoleh perkembangan diri yang baik. (Rahardjo \& Gudnanto, 2011 : 250)

Pada penelitian ini peneliti menggunakan jenis studi yaitu studi kasus. Sesuai dengan penjelasan bahwa studi kasus memiliki fokus untuk memahami suatu peristiwa (satu kasus atau kasus majemuk) berdasarkan sudut pandang individu yg terlibat dalam peristiwa yang sama serta peneliti ingin mengetahui secara rinci dan menyeluruh terhadap kasus ini

$$
\text { Pengumpulan data dalam }
$$
penelitian ini dilakukan melalui wawancara, observasi, dan studi pustaka. Wawancara yang dilakukan secara semi-structured interview, dimana peneliti memiliki satu daftar pertanyaan atau sering disebut dengan "panduan wawancara" tetapi informant memiliki kebebasan untuk menjawab pertanyaan. Observasi dilakukan ketika wawancara dilakukan, termasuk dari cara informant menjawab pertanyaan, serta mengamati beberapa tempat bisnis keluarga mereka. Studi pustaka diperlukan penulis sebagai bukti pendukung untuk mengetahui data-data sekunder.

Uji validitas data dalam penelitian ini dilakukan dengan triangulasi sumber yang diperoleh dengan melakukan wawancara dalam waktu yang berbeda juga membandingkan keadaan dan perspektif seseorang dengan berbagai pendapat dan pandangan orang lain. Triangulasi sumber dalam penelitian ini adalah Direktur Utama PT Triple S, yaitu Danny Budiadi.

\section{HASIL DAN PEMBAHASAN}

Penelitian dilakukan dengan menggunakan pendekatan studi kasus dengan tipe studi kasus eksploratif. Tipe studi kasus eksploratif ini digunakan untuk menyelidiki situasi yang masih belum jelas, dan hasil yang bersifat tunggal. Yin, (2003) dalam (Baxter \& Jack, 2008 : 548). Pada penelitian ini situasinya awal yang masih belum jelas adalah PT Triple $S$ dengan prestasinya di dunia internasional belum mampu membentuk brand awareness di dalam negeri, padahal PT Triple S melakukan kegiatan komunikasi pemasaran, namun mereknya di dalam negeri masih belum setenar diluar negeri.

telah dilakukan, peneliti dapat mengklasifikasikan enam bentuk kegiatan komunikasi pemasaran PT Triple S untuk target luar negeri, yaitu: (1) Mendapat sertifikasi kelayakan produk bola dari FIFA; (2) Kerjaasama 
dengan adidas dan masuk ke Piala Dunia 1998 Perancis; (3) Mengikuti kegiatan pameran di berbagai negara yang dianggap potensial; (4) membuat website perusahaan sehingga dapat diakses oleh publik luar; (5) liputan media massa mancanegara; dan (6) menaruh sampel produk bola dan brosur di KBRI yang melaksanakan ITPC (Indonesian Trade Promotion Center) dan satu faktor pendukung terbesar yaitu karakteristik konsumen luar negeri yang mempercaayai kualitas sebuah produk apabila telah terbukti dalam hal ini sertifikasi, dan produk bola sepak PT Triple S telah tersertifikasi oleh FIFA akan kualitasnya.

Dilihat dari pembahasan komunikasi pemasaran oleh Mahmud Machfoedz dan pembahasan Marketing Public Relations oleh Tom Harris, memang kegiatan yang dilakukan oleh PT Triple S adalah kegiatan yang dapat dikategorikan sebagai kegiatan komunikasi pemasaran seperti pameran, periklanan, spokesperson, liputan media massa, sponsorship, dan website. Namun ada yang tidak masuk kedalam kategori komunikasi pemasaran menurut Machfoedz dan Harris meski begitu kegiatan tersebut di klaim sebagai kegiatan komunikasi pemasaran oleh para manajemen perusahaan seperti menaruh sampel di KBRI yang menjalankan program ITPC dan kerjasama dengan Dinas Pendidikan.

Penelitian ini mengacu pada teori konstruksi sosial atas realitas yang dikemukakan oleh Berger dan Luckmann, asumsi dasar dari teori ini menyatakan bahwa segala realitas yang terjadi, ataupun fenomena yang ada semua merupakan hasil dari konstruksi manusia (Berger \& Luckmann, 1996:2). Secara umum konstruksi sosial adalah pembentukan kenyataan oleh masyarakat, meliputi proses eksternalisasi, objektifikasi dan internalisasi yang bersifat simultan dan saling terkait (Berger \& Luckmann, 1996:5) Hal di dalam kasus yang dikonstruksi dengan teori konstruksi sosial atas realitas adalah bagaimana manajemen pabrik dan para karyawan PT Triple S melakukan internalisasi dari brand Triple $\mathrm{S}$ pada benaknya, yang selanjutnya hasil dari internalisasi itu mereka kemudian melakukan eksternalisasi yang berupa suatu kegiatan yang dieksekusi dalam membentuk brand awareness di dalam negeri, dan objektivikasinya adalah pada benak pasar/masyarakat mengenai brand Triple S.

Pertanyaan penelitian kedua, mengenai faktor atau hambatan yang ada sehingga merek Triple S lebih dikenal diluar negeri daripada di dalam negeri. Pada dasarnya setiap kegiatan yang dilakukan dalam kepentingan mencapai tujuan baik itu kegiatan yang dilakukan individu atau sebuah perusahaan memiliki hambatan didalamnya. Termasuk kegiatan komunikasi pemasaran. Komunikasi pemasaran pada hakikatnya merupakan kegiatan komunikasi yang dibaurkan dengan ranah pemasaran, seperti yang diungkapkan Sutisna bahwa "komunikasi pemasaran merupakan usaha untuk menyampaikan pesan kepada publik terutama konsumen sasaran mengenai keberadaan produk di pasar." (Sutisna, 2002:267). Usaha penyampaian pesan tersebut adalah fungsi dari komunikasi, sementara menurut Joseph A DeVito mengenai definisi komunikasi adalah "communication is an act by one or more persons of sending and receiving messages that are distributed by "noise", 
occur within a context, have some effect and provide some opportunity" (DeVito, 1991:5). Melalui definisi komunikasi dari DeVito diketahui bahwa didalam proses komunikasi akan terdapat gangguan, gangguan tersebut dapat terjadi di elemen-elemen komunikasi yang ada sehingga menggagalkan proses komunikasi yang efektif, begitu juga di dalam komunikasi pemasaran. Berdasarkan hasil yang didapatkan di lapangan, faktor atau hambatan yang ada sehingga merek Triple $\mathrm{S}$ lebih terkenal di luar negeri daripada di dalam negeri dapat dibagi kedalam dua jenis, yaitu hambatan internal, dan hambatan eksternal.

Hambatan internal yang ada yaitu: (1) Kurang tepatnya analisis situasi yang dilakukan dalam melaksanakan kegiatan komunikasi pemasaran, dan (2) Belum ada SDM yang kompeten dalam menjalankan kegiatan komunikasi pemasaran. SDM PT Triple S sendiri merupakan optimalisasi keluarga karena PT Triple $\mathrm{S}$ merupakan perusahaan keluarga sehingga SDM yang ada belum tentu kompeten dalam menjalankan kegiatan komunikasi pemasaran, Sementara itu hambatan eksternal yang ada yaitu: (1) Karakteristik konsumen di Indonesia yang konsumtif namun lebih menyukai produk luar negeri untuk digunakan ketimbang produk dalam negeri, dan (2) Pada kerjasama dengan Dinas Pendidikan terdapat atmosfer persaingan yang kurang kondusif. Manurut pemaparan manajemen PT Triple $S$ hambatan yang paling sulit dilewati adalah karakteristik masyarakat Indonesia yang cenderung menyukai produk luar.

Pada salah satu jurnal yang merupakan salah satu review penelitian sejenis pada penelitian ini, ditulis oleh
Faik Kucuktopuzlu dengan judul The Kazakhstan In The Process Of Integration Into The Global Economy And Cultural Factors of Creating Brand Awareness mengatakan bahwa suatu nilai atau budaya dapat mempengaruhi pembentukan brand awareness. Sesuai dengan penjelasan tersebut bahwa hambatan eksternal yang dialami oleh PT Triple $\mathrm{S}$ berbentuk mindset atau karakteristik mayoritas masyarakat Indonesia, terbentuk dari nilai-nilai yang ada di masyarakat Indonesia dan menyebar hingga mayoritas masyarakat memiliki pemahaman nilai seperti hal tersebut.

Pemahaman nilai yang dianut mayoritas masyarakat Indonesia ini menjadi hambatan bagi perusahaan, khususnya PT Triple $S$ yang ingin membentuk serta meningkatkan brand awareness di dalam negeri. Selain itu Kucuktopuzlu juga melanjutkan bahwa perusahaan sebaiknya telah mempersiapkan hal tersebut dan ada strategi yang digunakan untuk mengatasi hambatan yang datang tersebut. PT Triple $S$ telah melakukan berbagai kegiatan komunikasi pemasaran, namun kegiatan tersebut hanya berdampak sedikit pada masyarakat dalam negeri, berdasarkan jurnal yang ditulis Kucuktopuzlu ini, PT Triple S sebaiknya memiliki strategi lain dalam mengatasi mindset masyarakat Indonesia mengenai hal tersebut yang dianggap menjadi hambatan perusahaan untuk mencapai tujuan. Oleh karena itu diperlukan langkah untuk menciptakan pemahaman konsumen yaitu dengan mencantumkan informasi yang jelas, memberi keterangan pada setiap produk yang disesuaikan dengan target yang dituju (Septiani, Sumartias, \& Perbawasari, 2017). 
Pertanyaan penelitian ketiga, mengenai upaya yang dilakukan PT Triple $S$ dalam meningkatkan brand awareness Triple $\mathrm{S}$ di dalam negeri. Hasil penelitian menunjukan bahwa PT Triple $S$ melakukan kegiatan komunikasi pemasaran yang masuk kedalam bauran promosi. "Kami melakukan kegiatan komunikasi pemasaran yang disebutkan tadi yaitu Pameran, sponsorship, website, liputan media yang selalu kami terima, dll." 6

Triangulator sekaligus Direktur Utama PT Triple S menyebutkan bahwa kegiatan komunikasi pemasaran PT Triple $S$ dengan beberapa platform komunikasinya adalah termasuk upaya dari PT Triple S dalam meningkatkan brand awareness perusahaan di dalam negeri. Bagi PT Triple $S$ komunikasi pemasaran adalah kegiatan komunikasi yang biasanya dilakukan oleh perusahaan dengan bertujuan untuk mencapai tujuan dari kegiatan pemasaran, yaitu memasarkan produk kepada kosumen, namun tidak hanya sekedar memasarkan, didalamnya terdapat aktivitas komunikasi yang memungkinkan perusahaan menyampaikan pesan mengenai produk ataupun perusahaannya melalui berbagai cara. Tidak hanya dari sisi perusahaan untuk menyampaikan pesan, melalui beberapa kegiatan komunikasi pemasaran juga membuat konsumen dapat memberikan feedback yang dapat diterima oleh perusahaan.

Menurut (Kennedy \& Soemanegara, 2006:119), tujuan komunikasi pemasaran adalah untuk mencapai tiga tahap perubahan, yaitu perubahan pengetahuan,perubahan sikap yang meliputi efek kognitif, efek afektif dan efek konatif, dan tujuan yang ketiga adalah perubahan perilaku. Hal yang diungkapkan tersebut sesuai dengan fakta dilapangan, berdasarkan data yang diperoleh dari lapangan bahwa kegiatan komunikasi pemasaran dilakukan PT Triple $S$ untuk memasarkan produkproduk olahraga mereka khususnya bola sepak, dan juga untuk membentuk brand awareness yang baik di dalam negeri. Hal tersebut merupakan sebuah upaya yang dilakukan dengan harapan tujuannya dapat tercapai. Tujuan membentuk brand awareness merupakan tahap perubahan pertama menurut (Kennedy \& Soemanegara, 2006:119) yaitu perubahan pengetahuan, dari yang tidak tahu menjadi tahu, dan dari yang sudah tahu menjadi lebih tahu lagi.

Pada faktanya berdasarkan hasil penelitian PT Triple $\mathrm{S}$ melakukan kegiatan komunikasi pemasaran adalah dengan tujuan untuk memasarkan produk dan membentuk serta meningkatkan brand awareness. Tujuan ini masuk kedalam tiga tujuan komunikasi pemasaran yang telah disebutkan sebelumnya pertama dengan harapan tujuan tersebut maka PT Triple $S$ berharap terdapat perubahan pengetahuan pada publik atau calon konsumen perusahaan, yang awalnya tidak tahu menjadi tahu, awalnya tahu menjadi semakin tahu terhadap merek Triple S.

Selanjutnya adalah perubahan sikap, diharapkan konsumen akan terdorong untuk membeli produk Triple $S$ dan kembali untuk melakukan pembelian terhadap produk Triple S. Ketiga adalah perubahan perilaku, diharapkan bahwa konsumen akan tetap menggunakan produk PT Triple S dan

\footnotetext{
${ }^{6}$ Hasil wawancara dengan triangulator pada 29 Juni 2015
} 
tidak berpindah ke produk lain. Setelah dijabarkan dapat dilihat yang mengawali langkah tersebut adalah perubahan pengetahuan yang artinya perusahaan perlu untuk membentuk dan meningkatkan brand awareness yang baik di mata publik. Adapun, "hubungan antara kepuasan dan loyalitas adalah dimana saat konsumen mencapai tingkat kepuasan tertinggi yang menimbulkan ikatan emosi yang kuat dan komitmen jangka panjang dengan merek perusahaan" (Anisa, 2016).

Berdasarkan hasil penelitian, terlihat bahwa PT Triple S melakukan kegiatan komunikasi pemasaran baik untuk target dalam maupun luar negeri. Terdapat kesamaan pada beberapa bentuk kegiatan komunikasi pemasaran yang dilakukan oleh PT Triple S untuk kedua target tersebut, seperti pameran, liputan media massa, website, dan sertifikasi FIFA, juga terdapat perbedaan bentuk kegiatan komunikasi pemasaran yang dieksekusi oleh PT Triple S di luar dan dalam negeri. Pada sisi jumlah kegiatan, bentuk kegiatan komunikasi pemasaran di dalam negeri lebih banyak namun nyatanya merek Triple $\mathrm{S}$ lebih dikenal di luar negeri ketimbang di dalam negeri, hal ini disebabkan faktor pendukung pada kegiatan komunikasi pemasaran PT Triple S diluar negeri yaitu karakteristik konsumen di luar negeri yang mayoritas mempercayai kualitas dari sebuah produk apabila telah terbukti, dalam hal ini contohnya adalah sertifikasi kualitas bola sepak PT Triple S oleh FIFA. Setelah mereka mengetahui sertifikasi tersebut maka mereka akan langsung percaya dengan kualitasnya.

Sebaliknya pada kegiatan komunikasi pemasaran di dalam negeri, terdapat hambatan baik internal maupun eksternal. Namun, berdasarkan hasil yang didapatkan penulis dari lapangan, faktor terbesar yang menghambat suksesnya kegiatan komunikasi pemasaran PT Triple S di dalam negeri adalah karena faktor karakteristik mayoritas konsumen di Indonesia yang lebih menyukai produk asing atau impor ketimbang produk dalam negeri sendiri. Meskipun pemerintah telah menggalakan "Cinta Produk Dalam Negeri" Namun pada kenyataannya masyarakat Indonesia masih lebih menyukai produk luar negeri ketimbang produk dalam negeri. Hal inilah yang menjadi faktor terbesar yang menghambat PT Triple S membentuk dan meningkatkan brand awareness yang baik di Indonesia, disamping hal tersebut terdapat pula hambatan lainnya yaitu keterbatasan SDM, karena pada dasarnya SDM PT Triple S merupakan optimalisasi dari keluarga sehingga SDM yang melakukan kegiatan komunikasi pemasaran belum tentu kompeten dalam melakukan kegiatan tersebut. Hal tersebut mengakibatkan merek PT Triple $S$ lebih dikenal di luar negeri ketimbang di dalam negeri sendiri.

\section{SIMPULAN DAN SARAN}

Berdasarkan hasil dari penelitian yang telah dilakukan peneliti yang berjudul "Komunikasi Pemasaran PT Triple S dalam membentuk Brand Awareness di Dalam Negeri" sejak pra riset hingga pengumpulan data dari lapangan, kesimpulan yang dapat ditarik adalah sebagai berikut:

PT Triple $S$ sebagai salah satu perusahaan besar yang bergerak dalam bidang produksi alat-alat olahraga, khususnya bola sepak dengan kualitas yang dinilai baik, bahkan dapat menembus pasar internasional serta dikenal di luar negeri memiliki masalah terkait brand 
awareness yang baik di dalam negeri. Padahal PT Triple $S$ sama-sama melakukan kegiatan komunikasi pemasaran baik di dalam maupun diluar negeri. Berdasarkan data yang diperoleh PT Triple $S$ kegiatan komunikasi pemasaran PT Triple $S$ yang berhasil sehingga mereknya dapat dikenal diluar negeri adalah, peningkatan kualitas bola melalui sertifikasi FIFA, kerjasama hingga masuk ke piala dunia, mengikuti pameran Internasional, menaruh sampel dan brosur di KBRI, dan peliputan meia massa.

Pada pelaksanaan kegiatan komunikasi pemasaran PT Triple S dapat dikatakan lancar berdasarkan hasil penelitian. Meski begitu tujuan dari kegiatan komunikasi pemasaran ini belum tercapai secara maksimal karena faktor hambatan yang ditemui. Sesuai dengan penjelasan informant bahwa karakteristik mayoritas masyarakat Indonesia adalah menyukai dan menggemari produk asing untuk mereka gunakan karena dinilai lebih bagus dan bergengsi termasuk produk alat olahraga dan bola sepak. Hal ini menjadi hambatan yang cukup sulit bagi PT Triple $S$ untuk ditembus, mengingat perilaku tersebut datang dari dalam diri masingmasing individu dari publik PT Trile $S$ di dalam negeri. Hambatan lainnya adalah karena PT Triple $S$ masih berstatus sebagai perusahaan keluarga, maka SDM yang ada didalamnya terutama bagian marketing dalam hal ini merupakan hasil optimalisasi dari anggota keluarga yang belum tentu kompeten dalam menjalankan tugasnnya.

Upaya yang dilakukan PT Triple S dalam meningkatkan brand awareness di dalam negeri adalah dengan meningkatkan kualitas produk mereka serta dilakukannya kegiatan komunikasi pemasaran di Indonesia dalam berbagai bentuk kegiatan seperti yang telah dijabarkan diatas. PT Triple $\mathrm{S}$ sendiri tidak memiliki Public Relations dalam perusahaannya, meski demikian PT Triple $S$ menjalankan beberapa kegiatankegiatan Public Relations salah satunya adalah kegiatan komunikasi pemasaran dalam rangka membentuk serta upaya meningkatkan brand awareness yang baik di dalam negeri

Saran untuk penelitian selanjutnya sebaiknya melihat dari bagaimana sisi Public Relations yang dapat meminimalisir atau bahkan mengatasi hambatan eksternal yang terjadi pada perusahaan, sehingga kegiatan-kegiatan Public Relations tersebut dapat berjalan dengan maksimal.

\section{DAFTAR PUSTAKA}

Anisa, R. (2016). Manajemen kerelasian pelanggan dalam menciptakan kepercayaan pelanggan pada. Jurnal Kajian Komunikasi, 4/1, 4451.

Berger, P. L., \& Luckmann, T. (1990). Tafsir Sosial atas Kenyataan: Risalah tentang Sosiologi Pengetahuan (diterjemahkan dari buku asli The Social Construction of Reality oleh Hasan Basari). Jakarta: LP3ES.

DeVito, J. A. (1991). Human Communication: The Basic Source. New York: Harper Collins.

Jack, P. B. (2008). Qualitative Case Study Methodology: Study Design and. The Qualitative Report Volume 13 Number 4 December 2008 544-559 , 548 . 
Machfoedz, M. (2010). Komunikasi Pemasaran Modern. Yogyakarta: Cakra IImu.

Prisgunanto, I. (2006). Praktek Komunikasi Pemasaran. Bogor: Ghalia Indonesia.

Rahardjo, S. \&. (2011). Pemahaman Individu Teknik Non Tes. Kudus: Nora Media Enterprise.

Septiani, G., Sumartias, S., \& Perbawasari, S. (2017). Pembentukan Brand Awareness Warunk Indomie Upnormal. Jurnal Profesi Humas, 1(2), 124-131.

Soemanegara, J. E. (2006). Marketing Communication - Taktik dan Strategi. Jakarta: PT buana Ilmu Populer (kelompok Gramedia).

Sutisna. (2002). Perilaku Konsumen \& Komunikasi Pemasaran. Bandung: PT Remaja Rosdakarya. 